doi:10.25143/sviv_2021_ISBN-9789934563751_38-43

\title{
Supervīzijas ieguvumi pedagogiem karjeras konsultantiem
}

\section{Kristīne Vende-Kotova, Rita Burceva}

Supervīzija izglītības vidē dod iespēju pedagogiem saskatīt pedagoǵiskā darba grūtības un analizēt tās, izvērtēt savus personiskos resursus profesionālo mērķu sasniegšanai, kā arī izvēlēties atbilstošāko rīcības veidu, lai risinātu problēmas (Blauzde, O. un Grohjacka, M., 2017). Kā skaidro Blauzde un Grohjacka, supervīzija izglītības vidē ir vērsta uz skolotāja profesionālās darbības problēmām un ir balstīta uz katra pedagoga personīgo profesionālo pieredzi. Tās mērķis ir uzlabot šo darbību, nevis to kritizēt. Turklāt tā palīdz nejusties profesionāli vientuļiem un piedāvā radošu vidi, kurā ir iespējams gūt iedvesmu un profesionāli pilnveidoties (Blauzde, O. un Grohjacka, M., 2017). Diemžēl nav rakstu un pētījumu par supervīzijas efektivitāti un nozīmīgumu tieši pedagogiem karjeras konsultantiem, izṇemot tālāk pieminēto Ritas Burcevas rakstu, tomēr var pieṇemt, ka arī uz viṇiem pilnībā attiecas iepriekš minētais.

Karjeras konsultantu profesijas standarts un sarunās ar viņiem paustais norāda uz l,oti plašu darbu loku, kas šiem speciālistiem ir jāveic: gan dokumentācijas veidošana karjeras atbalsta plānošanai un pasākumu īstenošanai, gan karjeras attīstības atbalsta pasākumu koordinēšana, organizēšana un vadīšana dažādām mērķgrupām, gan informācijas pieejamības nodrošināšana karjeras virziena izvēlei, savukārt pēdējos divos gados arvien lielāks uzsvars tiek likts uz individuālo karjeras konsultāciju nodrošināšanu izglītojamiem. Turklāt ir arī citas darbības jomas, kurās nepieciešamas daudzpusīgas prasmes un zināšanas. Ir nojaušams, ka šis darbs ne vien sniedz gandarījumu, bet ir arī diezgan izaicinošs - it sevišķi ņemot vērā, ka vairumam karjeras konsultantu ir arī citi darba pienākumi un/vai viṇi strādā vairāk nekā vienā izglītības iestādē (Valsts izglītības satura centrs, 2011). Jau vairākus gadus vispārējo un profesionālo izglītības iestāžu karjeras konsultantiem tiek piedāvātas supervīzijas, lai sniegtu atbalstu pienākumu veikšanā, pilnveidotu vinu profesionālo kompetenci, paaugstinātu pašrefleksiju un radītu atbalstošu vidi profesionālajai refleksijai. 
K. Vende-Kotova, R. Burceva. Supervīzijas ieguvumi pedagogiem karjeras konsultantiem

Rita Burceva 2019. gadā publicēja pētījumu, kurā ir apkopotas atsauksmes par 2018. gadā sniegtajām supervīzijām karjeras konsultantiem (Burceva, 2019). Tajā tika analizētas 183 anketas. Aplūkojot pētījuma rezultātus, redzams, ka visi 183 aptaujātie norāda, ka būtisks ieguvums bijis iepazīties ar citiem karjeras konsultantiem un satikt šos kolēǵus (veidojot jaunus kontaktus un sadarbību); 98\% norādīja, ka supervīzijās tika izglītoti par dažādiem profesionālās darbības aspektiem, 97\% ieguva jaunas zināšanas, 97\% identificēja jaunus izaicinājumus savā darbā un varēja reflektēt par līdzšinējo profesionālo pieredzi. Savukārt 96\% karjeras konsultantu norādīja, ka tika sekmēta viṇu profesionālā izaugsme un rosināta profesionālās atbildības izpratne. Tika minēti arī vairāki personiski ieguvumi, piemēram, supervīzija veicina pašanalīzi darba situācijās (92\%), palīdz izvērtēt riskus un iespējas (91\%), ieraudzīt jaunas iespējas (98\%), apzināties resursus (92\%) un paplašina redzesloku (98\%). Nozīmīgi, ka 27,3\% bija l,oti pozitīva, 71\% - pozitīva pieredze un tikai $0,5 \%$ bija negatīva, 1,1\% - l,oti negatīva supervīzijas pieredze. Kā redzams, karjeras konsultanti l,oti atzin̄̄gi novērtēja savu supervīzijas pieredzi.

Šì raksta mērķis ir iepazīstināt lasītājus ar karjeras konsultantu supervīziju ieguvumiem, balstoties uz aptauju rezultātiem. Aptauja tika izveidota, lai monitorētu supervīzijas darba izpildi un apzinātu karjeras konsultantu vajadzības un pieredzi. Arī 2019. gadā karjeras konsultanti, kuri apmeklēja supervīzijas, pēc to noslēguma tika aicināti anonīmi aizpildīt aptauju. Otrajā (2019. gada) aptaujā iegūtie dati tika analizēti apkopotā veidā, lai šoreiz, izmantojot jauktas metodes dizainu, noskaidrotu karjeras konsultantu apmierinātību ar supervīziju un viņu ieguvumus.

Lai realizētu izvirzīto mērķi, pētījumā tika izmantota šāda metodoloǵija:

- Instrumentārijs: pētījuma dalībnieki atbildēja uz deviņiem pētījuma jautājumiem, izvēloties vienu no atbilžu variantiem gradācijā no "pilnīgi nepiekrītu" līdz "pilnībā piekrītu". Viņiem bija arī iespēja atbildēt uz diviem atvērtiem jautājumiem: kādi bija mani nozīmīgākie profesionālie ieguvumi, un kādi bija mani nozīmīgākie personiskie ieguvumi?

- Pētījuma dalībnieki: trīs stundas (180 minūtes) garā vienreizējā grupas supervīzijā piedalījās 113 dažāda vecuma vispārējo un profesionālo izglītības iestāžu karjeras konsultanti. Supervīzijas notika visos Latvijas reǵionos, un dalība tajās bija brīvprātīga, iepriekš piesakoties. Supervīzijas sniedza supervizori, kuri ir ieguvuši izglītību supervīzijā, pēdējo trīs gadu laikā ne mazāk kā 45 stundas ir veikuši supervīzijas praksi un pēdējo trīs gadu laikā ne mazāk kā 30 stundu apjomā ir saṇēmuši supervīzijas par savu darbu.

- Pētījuma procedūra: aptaujas tika sagatavotas papīra formātā un iedotas supervīzijas grupas dalībniekiem pēc supervīzijas beigām. Dalība aptaujās bija anonīma.

- Datu analīze: kvantitatīviem rezultātiem tika izmantota aprakstoša pieeja, savukārt, analizējot atvērtos jautājumus, - tematiskā satura analīze. 


\section{Rezultāti}

Apkopojot aptaujas atbildes, konstatēts, ka karjeras konsultanti bija apmierināti ar supervīziju, jo apgalvojumam "supervīzija bija efektīva" pilnībā piekrīt 65,5\% supervizējamo, piekrīt - 34\%, un neviens aptaujātais nenorādīja, ka nepiekrīt vai pilnībā nepiekrīt apgalvojumam. Karjeras konsultanti arī loti pārliecinoši norādīja, ka viṇi ir pilnveidojuši savu profesionālo kompetenci, un tikai viens aptaujātais ir uzrakstīijis, ka nepiekrīt, savukārt 55,8\% - ka piekrīt, un 43,4\% - ka piln̄̄bā piekrīt. Visbeidzot, apgalvojumam, ka "supervīzija ir viṇam atbilstoša profesionālās pilnveides forma", $54 \%$ pilnīgi piekrīt, $44,2 \%$ piekrīt, tikai $1,8 \%$ jeb divi aptaujātie nepiekrīt, un nebija neviena, kas pilnībā tam nepiekristu.

Aplūkojot rezultātus par konkrētākiem ieguvumiem no supervīzijas, ir redzams, ka nozīmīgs daudzums norāda, ka supervīzijā tika veicināta prasme apzināties izglītojamā karjeras attīstības atbalsta vajadzības (55,8\% pilnībā piekrita, 41,6\% piekrita, tikai 2,7\% jeb trīs respondenti nepiekrita, un nebija neviena, kas pilnībā nepiekrīt), pilnveidotas refleksijas un sava darba analīzes prasmes (54,9\% pilnībā piekrita, $42,5 \%$ piekrita, tikai $2,7 \%$ jeb trīs respondenti nepiekrita, un nebija neviena, kas pilnībā nepiekrīt), un karjeras konsultants ieguva idejas un citus resursus efektīvākai kāda procesa vai situācijas vadībai problēmas risināšanā $(62,8 \%$ pilnībā piekrita, 36,3\% piekrita, tikai $0,9 \%$ jeb viens respondents nepiekrita, un nebija neviena, kas pilnībā nepiekrīt).

Aptaujā bija arī vairāki apgalvojumi, ar kuru palīdzību supervizējamie varēja norādīt savu attieksmi pret supervīzijas procesu. Apgalvojumam, ka karjeras konsultants "saṇēma no supervizora atbalstošu attieksmi, iedziḷināšanos, lai noskaidrotu notikumu patieso būtību", pilnībā piekrita $75,2 \%$, piekrita $24,8 \%$, un nebija neviena respondenta, kurš nepiekristu vai pilnībā nepiekristu. Vairums aptaujāto norādīja, ka viniiem bija pieņemamas metodes, kas tika izmantotas supervīzijā (66,4\% pilnībā piekrita, 32,7\% piekrita, tikai $0,9 \%$ jeb viens respondents pilnībā nepiekrita, un nebija neviena, kas nepiekrīt). Supervizējamos apmierināja arī supervizora kompetence, profesionālā pieredze un ètikas izpratne (85,8\% piln̄̄bā piekrita, 14,2\% piekrita, un nebija neviena, kas nepiekristu vai pilnībā nepiekristu šim apgalvojumam).

Atbildot uz jautājumu par karjeras konsultantu profesionālajiem ieguvumiem supervīzijā, tematiskajā analīzē izkristalizējās vairākas tēmas.

- Visnozīmīgākā tēma, kurai bija visvairāk satura vienību, bija metodes un idejas darbam. Šeit jāatzīst, ka vairākiem karjeras konsultantiem metodes un idejas darbam saistījās ar vairākām apakštēmām: par dažāda vecuma grupām, individuālo konsultāciju veikšanu, sadarbības veicināšanu ar skolēniem un viņu vecākiem, darbu ar kolēgiiem - mācību priekšmetu skolotājiem, idejām par pasākumu organizēšanu, sadarbību ar skolas administrāciju un klašu audzinātājiem, informāciju par pakalpojumu sniedzējiem, pieredzes apmaiņu par saskarsmi un sadarbību ar iestādes vadību. Piemēram: "Sapratu, 
K. Vende-Kotova, R. Burceva. Supervīzijas ieguvumi pedagogiem karjeras konsultantiem

ko un kā darīt, lai palìdzētu š̄ mācību gada 9. kl. absolventiem izvēlèties vidusskolas mācību priekšmetus", vai "Ieguvu idejas, kā motivēt skolènus apmeklēt individuālās konsultācijas".

- Nākamā nozīmīgā tēma ir kolēǵu pieredzes stāsti: karjeras konsultanti bija izjutuši vienotību un atbalstu, guvuši idejas un profesionālos kontaktus ar kolēǵiem un sapratuši, ka līdzīgas problēmas ir arī citiem, tādējādi izjūtot koleǵiālu vienotību un atbalstu. Piemēram: "Noderīgi pieredzes stāsti, kontakti un metodes, kuras pielietošu tuvākajā laikā", "Citu kolēǵu pieredze, domas, objektīvs un subjektīvs redzējums", "Idejas, kolēgu atbalsts. Atbalsts un sajūta, ka neesi viens".

- Emocionāli piesātināta bija tēma "Skats uz izmaiṇām profesijā nākotnē", kuras raksturošanai var minēt šādas satura vienības: "Mazliet izpratne par pedagogu karjeras konsultantu vietu Skola 2030", "Ieskats un idejas, kā pedagogi karjeras konsultanti iederēsies jaunajās kompetencēs, praktiska darbošanās", "Nevajag baidīties no pārmaiñām! Mierīgi jāstrādā tālāk".

- Cita nozīmīga tēma bija profesionālo problēmu apzināšana un risināšana, kur bija šādas satura vienības: "Apjaust karjeras izglītības atbalsta projekta problèmas, to aktualizācija, prasme risināt" vai "Ieguvu padomu, kā risināt situāciju".

- Vēl viena tēma bija profesionālo prasmju pilnveide un atziṇas, kur supervizējamo ieguvums bija šāds: "paņēmieni, metodes, kā aktualizēt jautājumus", "spēja reflektēt" un "sapratu, ka var būt dažādi komunikācijas veidi, ir jāpieñem atškirīgais".

- Pēdējā tēma bija attieksme pret pieredzēto supervīzijā, un te atbildes bija izteikti pozitīvas. Piemēram: "Esmu piln̄̄bā apmierināta. Liels paldies!", "Guvu iedvesmu turpmākajam darbam", "Supervizores attieksme un spēja aktualizēt dalībniekiem svarīgu jautājumu risināšanu" un "Es varēju pateikt savas šaubas un bažas".

Atbildot uz jautājumu par karjeras konsultantu personiskajiem ieguvumiem no supervīzijas, tematiskajā analīzē izkristalizējās vairākas tēmas.

- Arī pie šñ jautājuma - tāpat kā atbildot par profesionālajiem ieguvumiem supervizējamie norādīja, ka viṇu ieguvums bija idejas, piemēram, "dažādi ieteikumi par sava profesionālā darba organizēšanu turpmāk" un "idejas, ieteikumi, citu pieredze". Šai tēmai satura vienību bija skaitliski daudz mazāk nekā pie profesionālajiem ieguvumiem.

- L,oti nozīmīga tēma bija kolēǵu kontakti un atbalsts - ar uzsvaru, ka tieši kolēğu, nevis iespējamo sadarbības partneru kontakti. Dalībnieki bija izjutuši koleǵialitāti un savstarpēju atbalstu. Piemēram, "kolēǵu atbalsts un kontakti", "sajutu kolēgu emocionālo un profesionālo atbalstu" un "sociālais tīkls, kas tika papildināts ar jauniem kolēgu kontaktiem”. 
- Tēma, kas ietvēra personiskas atziņas par sevi un savu profesionālo darbību un kurā atbildes bija ḷoti atškikirīgas, bija jaunas atziṇas un secinājumi. Ieskatu par šo tēmu sniedz šādi piemēri: "Jāzina sevi, savas stiprās puses", "Caur profesionāliem ieteikumiem saklausīju sev personiski noderīgo", "cienīt sevi, palauties uz sevi".

- Kā nozīmīgu personisku ieguvumu vairāki karjeras konsultanti saredzēja darba motivācijas palielināšanos un profesionālo pašapziṇu. Piemēram, "Vèlme turpināt darboties, auga pašnovērtējums", "Apjausma par mana profesionālà darba pieredzes nozīmību" un "Apliecinājums, ka es strādāju pareizi. Sevis iegūtā apzinātā pārliecība".

- Ieguvums bija arī prasmju pilnveidošana, piemēram, "Nodarbību vadīšanas stratēgijas, metodes, virzīšana, veidojot pozitīvas un "ražĭgas" attiecības", "Pilnveidota prasme ieklausities".

- Tāpat vairāki supervizējamie minēja, ka supervīzijas grupa viņiem bija arī laiks sev un atpūtai, piemēram, "Relaksācija", "Mazliet sakārtojos", "Laiks sev" un "Ieguvu mieru un domu sakārtošanu".

- Cita tēma-emocionāli pozitīva pieredze, ko raksturo šādi piemēri: "Poziț̄ivas emocijas", "Pilnvērtīgi pavadìts laiks un apziña, ka viss būs labi!" un "Jēgpilni pavadìts laiks, pozitīvas emocijas".

- Vēl viena tēma - komunikācija supervīzijas grupā, un tai bija tikai pozitīvas atsauksmes, piemēram, "Jutos labi, saprasta, iedrošināta", "Laba grupa un korekta, ieinteresēta supervizore", "Uzmundrinājumi. Iespēja reflektēt un analizēt".

- Pēdējā tēma - pateicība supervizorei, kas ietvēra tādas satura vienības kā "Paldies supervizorei!", "L̦oti zinoša un prasmīga supervizore. Super!", "Labprāt apmeklēšu otro nodarbību".

Aplūkojot tematiskās analīzes datus kopumā, var secināt, ka, aprakstot gan savus profesionālos, gan personiskos ieguvumus, karjeras konsultanti, kuri piedalijjās supervīzijās, min šādus ieguvumus: jaunas idejas un metodes, kolēǵu pienesums (te gan jāmin, ka pie profesionālajiem ieguvumiem tas bija vairāk saistīts ar pieredzes apmaiņu, savukārt pie personiskajiem - pašu kolēgu kontakti un atbalsts), kā arī atziņas un prasmes, kas pie personiskajiem ieguvumiem bija vairāk saistītas ar cilvēka individualitāti, savukārt pie profesionālajiem - ar profesionālas dabas jautājumiem. Papildus pie profesionālajiem ieguvumiem ir jāmin šādas tēmas: attieksme pret piedzīvoto supervīzijā, profesionālo problēmu apzināšanās un risināšana un skats uz izmain̄ām profesijā nākotnē. Pie personiskajiem ieguvumiem papildus kopējām tēmām ir jāmin laiks sev un atpūta, darba motivācijas palielināšanās un profesionālās pašapziņas paaugstināšanās, komunikācija supervīzijas grupā un pateicība supervizorei. 
K. Vende-Kotova, R. Burceva. Supervīzijas ieguvumi pedagogiem karjeras konsultantiem

\section{Secinājumi}

Kā redzams, kvantitatīvās un kvalitatīvās daḷas rezultāti ir savstarpēji papildinoši un nav pretrunā cits ar citu. Aplūkojot tos, var secināt, ka pat pēc vienas trīs stundu garas supervīzijas pedagogiem karjeras konsultantiem ir daudzi un daudzveidīgi gan profesionāli, gan personiski ieguvumi. Salīdzinot ar R. Burcevas iepriekš veikto pētījumu (Burceva, 2019), arī šajā pētījumā konstatēti supervīzijas ieguvumi un tas, ka supervīzija karjeras konsultantiem ir l̦oti lietderīga un nepieciešama profesionāla atbalsta forma.

Tāpat būtu lietderīgi ne vien sniegt supervīzijas pakalpojumu, bet ar̄̄ turpināt apzināt, ko karjeras konsultanti supervīzijās vēlas gūt, veikt cita dizaina pētījumus un arī vērst uzmanību ne tikai uz ieguvumiem no supervīzijas, bet ar̄̄ aplūkot, ar ko supervīzijas procesā karjeras konsultanti nebija apmierināti vai kas viṇiem pietrūka.

\section{Avoti un literatūra}

Blauzde, O. un Grohjacka, M. (2017). Supervīzija pedagogu darbā. Sast. Mārtinsone, K., Mihailova, S. Supervīzija: Teorija. Pētījumi. Prakse. Rīga: Rīgas Stradiṇa universitāte, 178-184.

Burceva, R. (2019). Supervīzija pedagogiem karjeras konsultantiem. Society Integration. Education. 5, 53-68.

Valsts izglītības satura centrs. (2011). Karjeras konsultanta profesijas standarts. Iegūts no: https://registri.visc.gov.lv/profizglitiba/dokumenti/standarti/ps0367.pdf 